\title{
Globalization: The Challenge for Pakistan
}

\section{Khalil Hamdani*}

\begin{abstract}
This paper makes the case for Pakistan to engage actively in globalization. At present, the country is more a recipient of globalization than a participant. There is a need to shift the terms of engagement from passive to active involvement. Particular effort is needed to encourage foreign companies already present in Pakistan to integrate activities with their global operations. Export-oriented investment requires a more favorable trade regime. Above all, global engagement will require Pakistan to build up its technological capabilities substantially, both at the enterprise level and economy-wide. These shifts imply a revitalized industrial policy endorsed by industry and a vigorous policy thrust aimed at investment-led growth.
\end{abstract}

Keywords: Globalization, investment, trade, technology, industry, Pakistan.

JEL classification: F21, F63, O38, O53.

\section{Introduction}

The new globalism that unfurled in the mid-1980s continues to challenge countries, large and small, as well as international institutions created for an earlier era. Thirty years of globalization have witnessed deep financial crises as well as remarkable economic growth. On the positive side, a number of developing countries have made rapid progress. They have tapped into the worldwide flows of capital, technology, goods and services, and in the process they have vitalized their domestic industry and entrepreneurial activity, and accelerated the structural transformation of their economies. Surprisingly, Pakistan is not among this group of emerging economies.

It is surprising because the preconditions were right. Pakistan in the mid-1980s had, relative to other developing countries, a sound industrial base, a good technological infrastructure, and a fairly open policy regime.

\footnotetext{
* Visiting professor, Graduate Institute of Development Studies, Lahore School of Economics; former director, Investment Division, United Nations.
} 
The economy was, arguably, well positioned to engage in the cross-border connectivity unleashed by globalization. In many other respects as well its strategic location, large market, and language; its secular culture and pragmatic disposition - Pakistan was ready for globalization.

Without entering into the economic history of the past 30 years, it is apparent that Pakistan has remained on the margins of globalization while other developing countries - some in less fortunate circumstances - have advanced in the world economy. Of course, their advancement is independent of our slippage, but it is indicative of missed opportunities. Even as Pakistan's economy was seemingly flourishing, global trends downgraded its industrial base to low-tech, reclassified its exports as traditional, and raised the entry barriers for dynamic industries. Pakistan's paralysis is particularly disappointing as successive governments swallowed the bitter medicine of the Washington Consensus, but were unable to deliver the cure. Our discontents are understandable.

Nevertheless, there is need for Pakistan to engage more actively in globalization. This paper highlights a key feature of globalization international production - and suggests how it can be tapped in ways that modernize industry and better integrate the domestic economy into the world economy. All this will require national effort; successful participation in globalization involves more than policy liberalization and market orientation. It is also a challenge: the geopolitical landscape today is very different from that of the 1980s, the competitive setting is stringent, and policies are subject to international discipline. A fresh approach to industrial strategy is, therefore, needed.

\section{Globalization in Brief}

Globalization refers, simply, to the deepening of the world economy. There is greater trade, investment, technology, finance, and movement of persons between countries and within regions. The flows are multi-directional, intra-industry and, in some cases, volatile. This complex economic connectivity has multiple growth poles. National regimes conform increasingly to international agreements and standards. The world is not converging on one economy or one government - the number of political states has increased - but national economies are becoming more integrated with a global economy under common governance.

Globalization is an ongoing phenomenon. Historians say that the first big wave of globalization occurred before the First World War in a 
period marked by the expansion of international trade and integration of commodity markets, as well as outward investment and migration. ${ }^{1}$ There was a revival after the Second World War with the establishment of international institutions and successive rounds of tariff reductions. The integration of currency and financial markets ushered in a more turbulent period: the collapse of the Bretton Woods system of fixed exchange rates in 1973 and the debt crises of the early 1980s. The complications of financial globalization - systemic volatility and contagion - were felt once again, and severely in 1997 and 2008. At the same time, globalizing trends in the real sector evolved visibly in the mid-1980s with the expansion of capital and technology, and the integration of production across borders. These opened up opportunities for developing countries to grow rapidly, industrialize, and increase their participation in the world economy. It is this latter aspect of globalization that is of interest.

A key driver of this new globalism of the mid-1980s was foreign direct investment (FDI) and the related activity of transnational corporations (TNCs). ${ }^{2}$ Briefly, world FDI outflows grew by 24 percent per year in the second half of the 1980s and averaged a 10 percent annual increase over the next quarter century - an expansion that was significantly faster than that of world trade and world output (Figure 1). The surge in FDI was accompanied by an equally robust proliferation of nonequity TNC relationships (subcontracting, licensing, franchise and management ties), with an aggregate value exceeding that of FDI, thereby effectively doubling the real activity of TNCs.

The TNC expansion was initially to establish presence in industrial markets, driven also by mergers and acquisitions, and soon encompassed developing countries. This expansion began with TNCs'

\footnotetext{
${ }^{1}$ There were earlier episodes of connectivity centered on the slave trade in the West and along the Silk Road in the East. However, economic historians distinguish between the simple expansion of trade and its deeper impact on the integration of markets (O'Rourke \& Williamson, 2000). There was a significant change in the structure of the world economy in the 50 years before World War I (International Monetary Fund, 1997). Falling transport costs spread the technologies and division of labor of the Industrial Revolution worldwide. The distribution of world output shifted to Europe and North America from Asia and elsewhere; it is now rebalancing with the rise of the Global South (United Nations Development Programme, 2013). Generally, 1914 is considered a peak threshold, with world exports and imports together reaching 22 percent of world GDP (Estevadeordal, Frantz, \& Taylor, 2003) and the stock of foreign direct investment (FDI) reaching an estimated 9 percent of world GDP (Bairoch \& Kozul-Wright, 1996). These peaks were not surpassed until 1970 in the case of trade, and 1989 in the case of FDI.

2 The new globalism is discussed in Dunning and Hamdani (1997). A basic reference for data and analysis on FDI and TNCs is the World Investment Report (an annual series published by UNCTAD). Unless otherwise noted, the data in this article is drawn from the UNCTAD database (http://unctadstat.unctad.org).
} 
acquisition of or investment in standalone affiliates, followed by the integration of their operations along the value chain. The expansion, driven by digital technology, began in manufacturing and advanced to the offshoring and outsourcing of services. Through foreign production, TNCs penetrated overseas markets, lowered costs and raised the value added. The annual sales of their foreign affiliates now exceed world exports of goods and services. TNCs also dominate in other areas: 80 percent of world trade involves TNCs (as buyers and/or sellers) and they account for upward of 75 percent of global research and development.

Figure 1: Expansion of world FDI

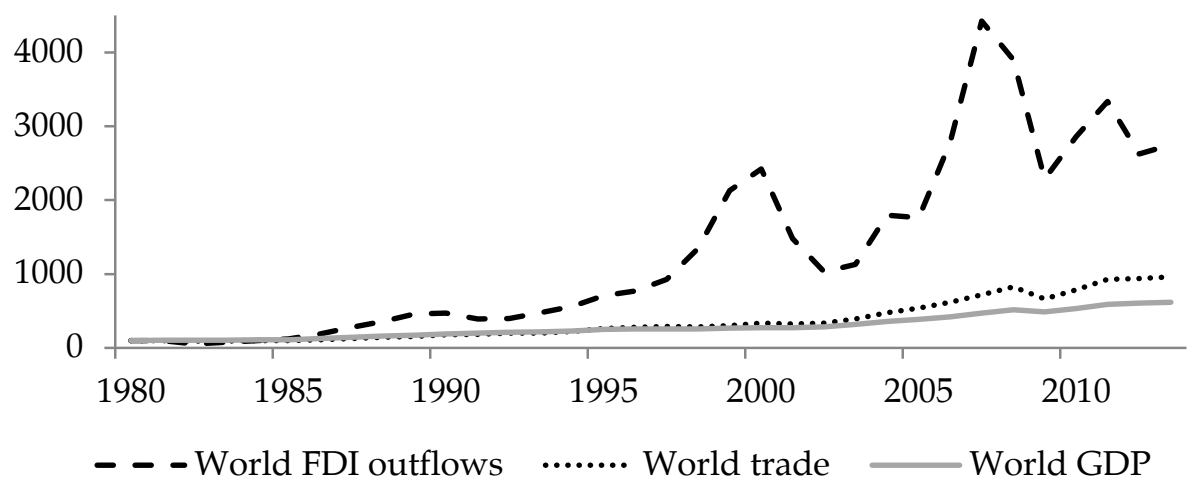

Note: Index $1980=100$.

Source: UNCTAD (http:/ / unctadstat.unctad.org).

A measure of the resultant globalization is the rise in the stock of world FDI, from 7 percent of world GDP in 1985 to 36 percent in 2013. Trade in goods and services, driven by TNCs, increased from 35 percent of world GDP in 1985 to 62 percent in 2013. The deepening of the world economy is reflected in the changing character of cross-border exchange, which is no longer arm's-length between independent buyers and sellers, and is increasingly within corporate supply chains with international production fragmented in different locations and coordinated by regional and global headquarters. Services have become tradable and manufactures now trade as commodities - bought and sold in large numbers without regard to brand or origin.

The globalization of developing countries is reflected in their trade and investment. Their imports and exports rose from 44 percent of their GDP in 1985 to 70 percent in 2013. Their inward stock of FDI rose from 14 percent of their GDP in 1985 to 31 percent in 2013, while the 
corresponding increase in their outward stock of FDI was from 3 percent to 19 percent. Importantly, opportunities opened up for developing countries to diversify away from resource- and labor-intensive production and participate more in dynamic industries, and to upgrade into higher-value segments of the world economy. Developing countries captured more than 70 percent of the trade in parts and components, which constituted more than 50 percent of the growth in world manufactured exports. Developing countries also increased their share of world services exports, from 20 percent in 1985 to 30 percent in 2013. Overall, developing countries have grown faster than the world economy; among them, the major exporters of manufactures grew most rapidly (Table 1$)$.

Table 1: Economic growth (average annual growth rates in real GDP, \%)

\begin{tabular}{lccc}
\hline & $\mathbf{1 9 8 0 - 8 9}$ & $\mathbf{1 9 9 0 - 2 0 0 0}$ & $\mathbf{2 0 0 0 - 1 0}$ \\
\hline World & 3.3 & 2.9 & 2.8 \\
Developing countries & 3.5 & 4.9 & 6.1 \\
$\begin{array}{l}\text { Developing countries: major } \\
\text { exporters of manufactures }\end{array}$ & 6.0 & 6.7 & 7.0 \\
\hline
\end{tabular}

Source: UNCTAD (http:/ / unctadstat.unctad.org).

The East Asian economies were particularly successful in seizing the opportunities presented by globalization. Although Japan, the Republic of Korea, and Taiwan, China, did not rely on inward FDI when they industrialized in the 1950s and 1960s, they all relied on technology transfers through nonequity relationships with TNCs (licensing and subcontracting) to catch up with advanced countries. Importantly, their own firms later became global players through "flying geese" outward FDI. In the mid-1980s, Japanese automobile companies gained a competitive advantage in the markets of the US and Europe by fragmenting production processes and relocating simpler tasks (such as assembly) to lower-cost sites across Southeast Asia.

A similar pattern of complex international production emerged in electronics, with Korean and Taiwanese firms upgrading from original equipment manufacturing (OEM) to higher-value design and marketing, and relocating the manufacture of parts and components elsewhere in East Asia, including China. Asian FDI pulled in Western FDI. Thus, in the mid1980s, the first-tier Asian "tigers" (in particular, Korea and Taiwan) upgraded from the export of low-technology products to medium- and high-technology products; the second-tier East Asian economies (in 
particular, Malaysia and Thailand) graduated from the export of resourcebased to low-skill manufactures. China advanced from the export of primary commodities to manufactures, emerging as the world's factory.

A key feature of the Asian experience was the emphasis on active national policies to build up domestic technological capabilities. Their aim in technology transfer went beyond acquisition of machinery and methods, and sought to learn and master production processes. They invested in education and human resource development, and provided training, managerial programs, and technical and financial support to help establish industry. Subsidies for and protection of the domestic market for infant industries remained relevant, but the real ladders for catch-up and rapid industrialization were the procurement of external technological inputs and the promotion of exports. Production catered to world demand, not domestic demand. This was natural for small economies, but even China, with a huge internal market, saw advantages in attracting FDI into special economic zones in order to tap external assets and develop capabilities to export to the world economy. This outward-oriented industrial policy was important to the success of East Asia.

Globalization makes catch-up easier, but also makes learning more important. The fragmentation of production into global value chains allows developing countries to participate in the manufacture of sophisticated products without progressing through the industrial path typically associated with hosting a standalone production facility. It hastens catch-up by easing entry into complex production through lowskill assembly operations. However, progression to more complex operations requires productive workers - educated, disciplined, with the capacity to learn new skills quickly. Thus, complex international production flattens the industrial learning curve at lower activity levels and steepens it at higher levels. The emphasis on technological learning allowed the East Asian countries to tap the entry opportunities that globalization opened up and, importantly, prepared them for the advance to higher levels.

While globalization has lowered the entry barriers to industrialization, progression within the product space can be difficult. Upgrading from low-skill to higher-skill production requires technological effort. At the same time, low-skill products increasingly occupy the less dynamic segments of world trade. The geographic shift in manufacturing from developed countries to a larger number of developing countries with a greater propensity to export has intensified 
competition for market share and worsened the overall terms of trade for unskilled and low-technology products (fallacy of composition).

A case in point is the manufacture of garments: the number of developing countries exporting clothing to the US doubled between 1980 and 1995, but export prices for garments have declined since then (UNCTAD, 2005). Moreover, falling export prices increase global demand and encourage countries to expand output further rather than to innovate and diversify production. Thus, improved export performance need not lead to structural change. In the absence of technological learning and supportive industrial policy, progression toward more sophisticated production is impeded and industrialization is stunted.

Finally, globalization has revived the need for industrial policy, but with less focus on protecting infant industries and more on nurturing global players. International production involves continuous innovation: manufacturing is in constant makeover and processes become outmoded rapidly. Openness to trade and investment stimulates enterprises to learn new methods through cross-border connectivity (e.g., buyer-seller relationships, global value chains, and overseas presence). Protection creates a blind spot that can lead to a loss of competitiveness. At the same time, if the rate of technological obsolescence exceeds the rate of depreciation of physical capital, domestic enterprises may underinvest in upgrading their production processes. There is, therefore, a role for public institutions and policies to help enterprises close the blind spot and, as appropriate, bridge the divergence between obsolescence and depreciation.

Much depends on the economic context: in some cases, vintage technologies may be cost-effective; in other cases, leapfrogging to the technological frontier may be competitive. The decision rests with the enterprise, but the government can remove hurdles through financial support, infrastructure development, and policies that promote horizontal linkages (e.g., industrial clusters) and vertical linkages (e.g., supply chains) among enterprises, large and small, domestic and foreign. Also relevant are innovation partnerships that foster linkages and cooperation between the science, civic, and business communities (e.g., training, technical advice, and research institutes). The East Asian experience suggests the success of smart industrial policy based on the use of foreign capital and technology, the development of domestic capabilities, and nurture of key industries. 


\section{The Challenge for Pakistan}

For Pakistan, the challenge of globalization is to position the economy within the evolving constellation of cross-border relationships so as to seize opportunities for rapid growth. At present, the country is more a recipient of globalization than a participant and needs to shift its terms of engagement from passive to active involvement.

On the plus side, Pakistan has benefitted well from the crossborder movement of workers. Pakistani workers going overseas are a form of outward investment that has returned large flows of remittances to the home economy. These remittances have had micro-benefits for lowincome groups and poverty alleviation, and macro-benefits by stimulating domestic demand among a rising middle class and relaxing external resource constraints. Remittance receipts increased from 1 percent of GDP in 2000 to 7 percent in 2013, and the growth in remittances has outpaced the growth in trade.

On the negative side, Pakistan has been complacent on investment and exports. It was not a major recipient of the worldwide surge in FDI. There was little FDI in manufacturing, and mainly in the extractive sector, which generates few economic spillovers. The FDI in services (e.g., banking and telecommunications) was beneficial, but entailed foreign outflows of profits and dividends (Hamdani, 2013). Pakistan has also not entered the dynamic segments of world trade and was a latecomer to international production and global value chains. It imports technology-intensive goods, but does not export technology-intensive products. The country's major manufactured exports are labor-intensive textiles and garments, which compete in a saturated world market with declining terms of trade.

While Pakistan's foreign trade (Figure 2) and investment (Figure 3) have been more open than those of its neighbors since the 1980s, the latter have performed better. All three South Asian economies export textiles, but India has also diversified its export structure and avoided declining terms of trade, while Bangladesh has attracted FDI in garments to become a top global exporter, moving up the value chain from "cut, make and trim" to OEM.

Complacency has placed the Pakistan economy on an unsustainable growth path. For some years, investment and large-scale manufacturing have been stagnant and growth has been driven by consumption (World Bank, 2014). The consumption boom has boosted 
the services sector and small enterprises, but largely bypassed manufacturing (Nabi, 2010). A rising middle class demands consumer goods that remittances finance from abroad. The dream of the common man - in the vernacular of pulp fiction - is "to get filthy rich in rising Asia" (Hamid, 2013). Although the government has managed the external balance reasonably well, a preoccupation with short-term stability neglects the need for dynamic growth. The economy cannot sustain high consumption with low investment growth. Indeed, Pakistan's economic growth has been slowing down relative to that of its neighbors and the average for developing countries (Figure 4).

Figure 2: Trade openness (exports and imports as \% of GDP)

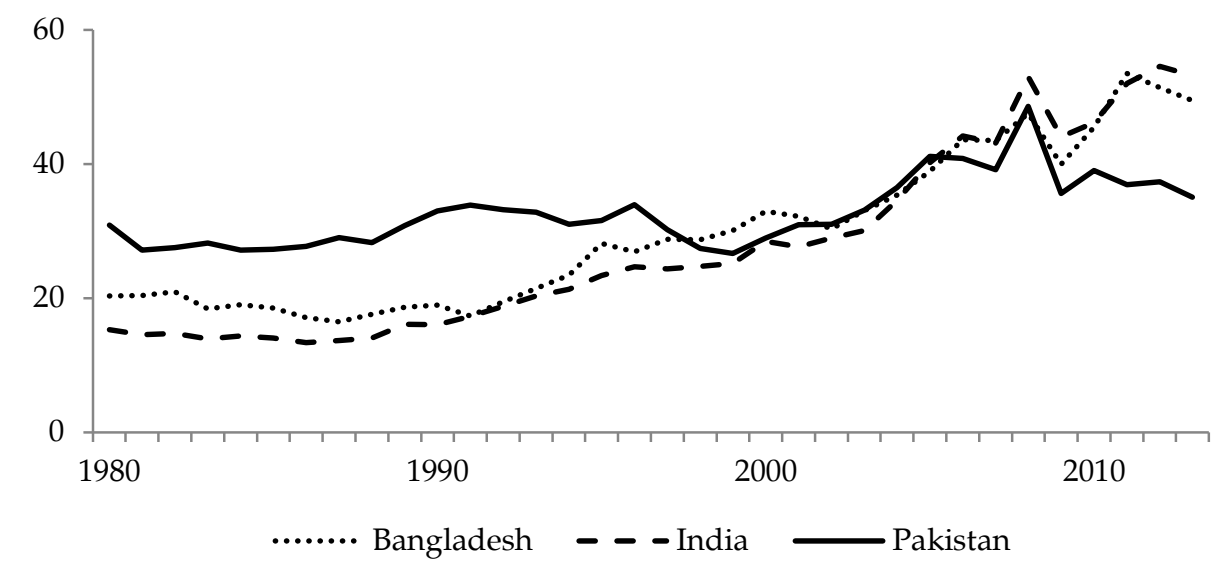

Source: UNCTAD (http:/ / unctadstat.unctad.org).

Figure 3: Investment openness (FDI inward stock as \% of GDP)

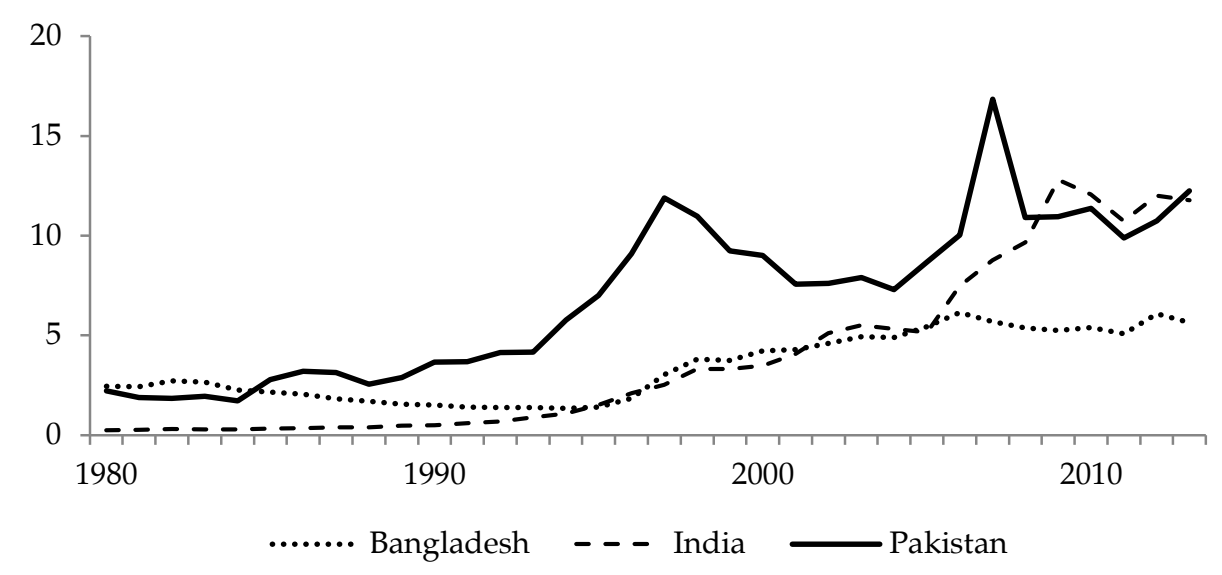


Source: UNCTAD (http:/ / unctadstat.unctad.org).

Figure 4: Economic growth (average annual rates in real GDP, \%)

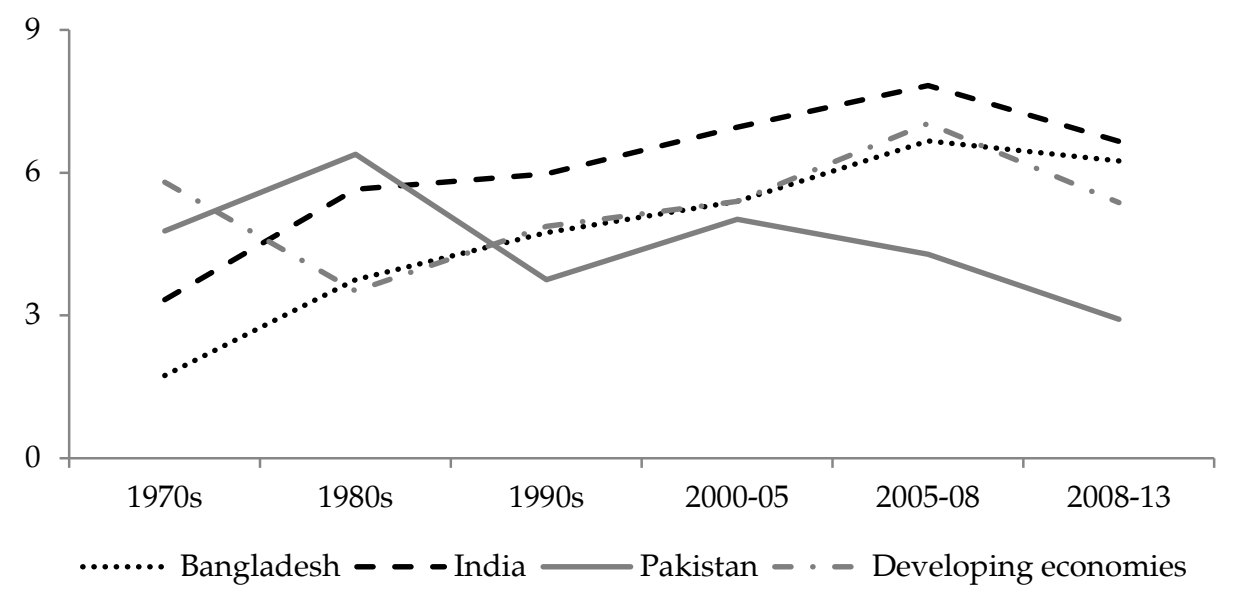

Source: UNCTAD (http:/ / unctadstat.unctad.org).

The Pakistan experience illustrates three half-truths about globalization. One is the notion that large economies do not need to globalize. The view - long popular in South Asia - that small economies need an external engine of growth, but that large economies can develop on the strength of domestic demand is a half-truth. China, as previously noted, is the counterfactual: a large economy achieving double-digit growth in manufacturing through exports.

A second half-truth is that openness defines success - this is necessary but not sufficient. Pakistan was more open than its neighbors, but was unable to translate its lead into successful integration. A third halftruth is that technology is a quick fix. Technology transfer and acquisition expedite catch-up, but keeping up requires learning and mastery. Like East Asia, Pakistan acquired technology from abroad, but the emphasis here was on importing capital goods, even entire turnkey plants and factory complexes. Unlike East Asia, little attention was paid to technological learning (Weiss \& Lall, 2004). Thus, Pakistan's industry today depends on continuous technology transfer; its technological capabilities have not emerged as a driver of industrialization as in East Asia.

Putting all three half-truths together yields an intractable predicament for Pakistan: industry constrained by imports is unable to keep up with the booming domestic demand of a large economy. 
Manufacturing is stagnant but, luckily, services are flourishing and creating jobs, although rising incomes are further fuelling the consumption of goods that domestic enterprises are unable to supply.

\section{Toward Active Engagement}

Pakistan is better placed than most developing countries to participate in and benefit from globalization. In spite of everyday difficulties - security, energy - multinationals rank Pakistan among the next emerging economies. However, foreign investors should see Pakistan not only as a market for selling, but also as a location for international production.

Pakistan attracts extractive and market-seeking FDI, and not exported-oriented FDI. This is understandable. The economy has natural resources and a large internal market of 180 million persons. These inherent advantages are attractive to foreign investors. FDI in the extractive industries has been resilient in spite of the uncertain investment environment. Market-seeking FDI has also been forthcoming over the years in consumer industries (food and beverages, household appliances, pharmaceuticals, vehicles) and, more recently, in services (banking, telecommunications, retail). Pakistan can certainly receive more such FDI and derive greater benefits from it, but it can also attract efficiency-seeking FDI.

Typically, developing countries with small markets and few natural resources have little to offer foreign investors other than abundant supplies of low-wage labor. The stereotype is the fly-by-night investor that sets up a sweatshop to stitch cheap T-shirts for export and then moves on to cheaper - more "efficient" - locations. Clearly, we do not need such foreign investment; we already have our share of domestic sweatshops. However, a notable feature of efficiency-seeking FDI is that it connects the local economy with the world economy, providing a point of entry toward upgrading into higher-value activities and for tapping into the global supply chains of TNCs. With the right kind of efficiencyseeking FDI, Pakistan's manufacturing could jumpstart a return to the world industrial frontier.

Particular effort is needed to encourage foreign companies already present in Pakistan to integrate these activities with their global operations. Japanese automobile companies, for example, invest differently in Pakistan and in East Asia. Their activities here involve the 
assembly of imported components for local sale. Their investments in East Asia are integrated with complex regional production systems involving assembly for local sale as well as the local manufacture of selected parts for export within the corporate network. Thus, the policy objective of global integration is broader than increasing local content in standalone operations; it aims to encourage production processes that are linked to, and upgradable with, the company's worldwide technological advancement.

Traditionally, investors submit and the government approves standalone investment proposals that focus on the more lucrative extractive and market-seeking opportunities. A broader approach is desirable. Ideally, both parties should jointly develop investment plans that leverage Pakistan's resources and market advantages in support also of export-oriented operations. This calls for a more proactive role for the government, going beyond project approvals and working with industry to create an enabling environment for investment in export production.

Export-oriented investment requires a favorable trade regime. Although the Pakistan economy is relatively open, its trade policy reflects an anti-export bias. A large number of statutory regulatory orders (SROs) complicate the incentive regime and orient it toward licensing imports rather than promoting exports (Pursell, Khan, \& Gulzar, 2011). In the case of the country's major export, import controls on technical inputs discourage textile exporters from moving up the garment value chain (Hamid, Nabi, \& Zafar, 2014). In other areas, Pakistan has not taken advantage of regional agreements, competing more with low-income countries for preferences in traditional markets rather than negotiating trade agreements with dynamic economies (Kaukab, 2014). Nor has it fully implemented its regional trade and transit agreements in South Asia, West Asia, and Central Asia (Ahmad, 2014). The country's rankings on trade facilitation and the cost of doing business have also slipped in recent years (Saeed, 2014). These weaknesses need to be corrected and the institutions dealing with trade policy need a clear export mandate.

Global engagement requires technological capabilities. It bears repeating that policy liberalization permits global engagement, but does not guarantee success. FDI brings with it technology, but does not guarantee technological learning. Participation in global supply chains provides access to world markets, but does not assure advancement up the value chain. Successful globalization requires building capabilities at the enterprise and economy levels. There is clearly a role for industrial 
policy, but the experience is varied and there is a pertinent lesson to draw from the Indian Planning Commission's (2011, p. 50) years of experience:

Support to the enterprises should be in such a way that it motivates and enables enterprises to learn and develop complex capabilities and not become complacent and inefficient, which was the outcome of the industrial policy adopted by India until the 1980s.

In East Asia, industrial policy is a joint undertaking of the government and industry, where the role of the public sector is to support and not "crowd out" the private sector, and where such support is linked to enterprise performance. On their part, governments have promoted investment in industries with potential for learning, scale economies, and productivity growth; encouraged forward and backward linkages that stimulated investment in the wider economy; and eased constraints to capital accumulation, particularly on capital good imports. On its part, industry has earned high rents, but also reinvested profits to increase productivity and output growth. There were also large public expenditures in education (particularly in science and engineering) and technology diffusion (involving research centers and support services for SMEs).

This experience has relevance for Pakistan. In particular, there is need for a stronger relationship between government and industry, and shared views on: (i) tackling the urgent problems of energy, security, and investor confidence; (ii) practical matters of regulatory barriers that impede entrepreneurship and business; and (iii) strategic plans for industrial upgrading. While the latter plans may focus vertically on specific industries, much industrial policy is implemented horizontally through instruments such as competition policy, export policy, regulatory frameworks, and health and environmental standards, which apply to all industries and all enterprises, foreign and domestic, large and small.

Finally, Pakistan has a number of scientific organizations that should be deployed in support of the enterprise sector through research programs, industrial clusters, and technical advisory services for SMEs. There is a continuing long-term need for greater public expenditure on education and physical infrastructure. The large annual expenditures to maintain state-owned enterprises could be better allocated to the development budget. Inefficient state enterprises are not only a drain on public resources, but are also a burden on downstream industries. The inefficiencies of Pakistan Steel, for instance, have impeded the engineering 
sector (see Kemal, 2005, p. 51). The benefits of divestiture are apparent in the total productivity gains for the overall economy that flowed from privatizations in the banking and telecommunications sectors.

\section{Conclusion}

Pakistan is strategically located to be a regional manufacturing hub. Although an ambitious goal for a latecomer, it illustrates the grand visionary design expected of a development state. Moreover, China's recent announcement to make a five-year investment in the US $\$ 46$ billion Pakistan-China Economic Corridor suddenly makes that goal less audacious.

The government must sustain the momentum with a vigorous policy thrust to support investment-led growth. A high GDP growth target is meaningless unless driven mainly by investment (and not consumption). This requires a revitalized industrial policy endorsed by industry. The policy should address the technological weaknesses of the manufacturing sector. Complementing the focus on domestic industry are dual needs: (i) to incentivize trade, particularly exports; and (ii) to attract FDI for exports, working with foreign companies already present in Pakistan to integrate those activities into their global operations.

Pakistan is a latecomer to globalization, but the nature of the process is such that rapid advance is possible with smart policymaking and determined collective effort. The challenge is not beyond reach. 


\section{References}

Ahmad, M. (2014). Improving regional trade to support Pakistan's economic growth [Special edition]. Lahore Journal of Economics, 19, 461-469.

Bairoch, P., \& Kozul-Wright, R. (1996). Globalization myths: Some historical reflections on integration, industrialization and growth in the world economy (Discussion Paper No. 113). Geneva: UNCTAD.

Dunning, J. H., \& Hamdani, K. (Eds.). (1997). The new globalism and developing countries. Tokyo: United Nations University Press.

Estevadeordal, A., Frantz, B., \& Taylor, A. M. (2003). The rise and fall of world trade, 1870-1939. Quarterly Journal of Economics, 118(2), 359407.

Hamdani, K. (2013). Benefiting from foreign direct investment. In R. Amjad \& S. J. Burki (Eds.), Pakistan: Moving the economy forward. Lahore: Lahore School of Economics.

Hamdani, K. (2014). Foreign direct investment and technological capabilities: The relevance of the East Asian experience for Pakistan [Special edition]. Lahore Journal of Economics, 19, 267-281.

Hamid, M. (2013). How to get filthy rich in rising Asia. New York, NY: Penguin.

Hamid, N., Nabi, I., \& Zafar, R. (2014). The textiles and garments sector: Moving up the value chain [Special edition]. Lahore Journal of Economics, 19, 283-306.

India, Planning Commission. (2011). The manufacturing plan: Strategies for accelerating growth of manufacturing in India in the 12th Five-Year Plan and beyond. Retrieved from http://planningcommission.gov.in/aboutus/committee/strgrp12 /str_manu0304.pdf

International Monetary Fund. (1997). Globalization in historical perspective [Annex]. In World Economic Outlook (pp. 112-116). Washington, DC: Author. 
Kaukab, R. S. (2014). The changing landscape of RTAs and PTAs: Analysis and implications [Special edition]. Lahore Journal of Economics, 19, 411-438.

Kemal, A. R. (2005). Industrialization and S\&T policies of NIEs and parameters for success (chap. 2). In A. Rahman, A. R. Kemal, R. Siddiqui, M. Din, Z. M. Nasir ... S. H. Khan (Eds.), Science- and technology-based industrial vision of Pakistan's economy and prospects of growth. Islamabad: Pakistan Institute of Development Economics.

Nabi, I. (2010). Economic growth and structural change in South Asia: Miracle or mirage. Lahore: Lahore University of Management Sciences, Development Policy Research Centre.

O'Rourke, K., \& Williamson, J. (2000). When did globalization begin? (Working Paper No. 7632). Cambridge, MA: National Bureau of Economic Research.

Pursell, G., Khan, A., \& Gulzar, S. (2011). Pakistan's trade policies: Future directions (Working Paper No. 11/0361). London: International Growth Centre.

Saeed, M. (2014). The WTO Trade Facilitation Agreement: Implications for Pakistan's domestic trade policy formulation [Special edition]. Lahore Journal of Economics, 19, 439-460.

United Nations Development Programme. (2013). Human development report 2013 - The rise of the south: Human progress in a diverse world. New York, NY: Author.

Weiss, J., \& Lall, S. (2004). Industrial competitiveness: The challenge for Pakistan. Islamabad: Asian Development Bank.

World Bank. (2014). Revitalizing industrial growth in Pakistan: Trade, infrastructure, and environmental performance. Washington, DC: Author. 